\title{
Assessing the Contribution Factors for the Enhancement of Green Building Index (GBI) in the Malaysian Construction Industry
}

\author{
(Penilaian Faktor Sumbangan untuk Peningkatan Indeks Bangunan Hijau (GBI) dalam \\ Industri Pembinaan di Malaysia)
}

Yeong Liang Sim*, Frederick Putuhena, Puong Ling Law \& Azhaili Baharun

\begin{abstract}
This research paper focuses on the several most crucial organisation factors that directly influence the Green Building Index (GBI) in the Malaysian construction industry. The findings of the paper are based upon a comprehensive literature search and empirical studies conducted with 102 construction firms in Malaysia. All these firms are selected based on firm sizes of 50 people and above within the organisation. Seven internal organisation factors are correlated with five external factors for the improvement of the green construction organisation. The study used Canonical correlation methods to correlate simultaneously the internal factors to the assessment of the improvement for the organisation. In summary it can be stated that the overall level of organisation factors are medium and there are rooms for improvement. The most important internal factors that influence the Malaysian construction projects were found to be 'Environmental/Green Technology', 'Training' and 'resistance to change. The least important factors were documentation and usage of computer technology. On the other hand, external factors that influence projects green performance were found to be 'Integration with Environmental Management', 'New Approaches to Management' and 'Shifting Customer Expectations' The findings suggest that the integration of several factors as the preferred option for the enhancement of the green performance within the Malaysian Construction Industry. Senior Management can utilise these factors to assess their strengths and weaknesses on the organisation practices necessary for the effective deployment in construction projects.
\end{abstract}

Keywords: Green building index (GBI); green technology; organisational factors; environmental management; construction

\section{ABSTRAK}

Kertas penyelidikan ini memberi tumpuan kepada beberapa faktor-faktor organisasi yang paling penting yang mempengaruhi Indeks Bangunan Hijau (GBI) di industri pembinaan Malaysia secara langsung. Hasil karya ini adalah berdasarkan kajian literasi yang komprehensif dan kajian empirikal dari 102 syarikat pembinaan di Malaysia. Kesemua syarikat-syarikat ini telah dipilih berdasarkan saiz organisasi untuk 50 orang dan ke atas. Tujuh faktor organisasi dalaman dikorelasi dengan lima faktor luaran bagi penambahbaikan organisasi pembinaan hijau. Kajian ini menggunakan kaedah korelasi Canonical untuk mengaitkan faktor-faktor dalaman dan penilaian terhadap peningkatan dalam organisasi. Secara ringkasnya tahap keseluruhan faktor-faktor organisasi adalah sederhana dan mempunyai banyak ruang untuk penambahbaikan. Faktor-faktor dalaman yang paling penting dalam mempengaruhi projek pembinaan Malaysia adalah 'Teknologi Alam Sekitar / Green', 'Latihan' dan 'rintangan kepada perubahan'. Faktor-faktor yang didapati kurang penting ialah 'Dokumentasi' dan 'Penggunaan teknologi komputer'. Sebaliknya, faktor-faktor luaran yang mempengaruhi prestasi projek-projek hijau adalah 'Integrasi dengan Pengurusan Alam Sekitar', 'Pendekatan Baru untuk Pengurusan' dan 'Peralihan Pelanggan'. Penemuan kajian mencadangkan bahawa integrasi beberapa faktor yang lebih popular boleh meningkatkan prestasi hijau dalam Industri Pembinaan Malaysia. Pengurusan syarikat boleh merujuk kepada faktor-faktor ini untuk menilai kekuatan dan kelemahan prestasi organisasi dan memilih faktor yang diperlukan untuk pelaksanaan yang berkesan dalam projek-projek pembinaan organisasi.

Kata kunci: Indeks bangunan hijau (GBI); teknologi hijau; faktor organisasi; pengurusan alam sekitar; pembinaann

\section{INTRODUCTION}

This paper presents the findings of the contribution factors that applicable to the development of Green Building Index (GBI) in Malaysia. The literature review establishes that significant amount has already been written on within the Malaysian context, however little research has been conducted to investigate and thus developing the sustainability and green policy as outlined in the $11^{\text {th }}$ Malaysian Master Plan. Against this background and 
with the growing of Malaysian economy, customers have had much choice of products. Recent years had seen much attention and initiatives provided by government of Malaysia in the effort to bring the local construction industry up a par with those of developed countries (Sim 2015). Wider choices have elevated quality requirements and pose another challenge. In this dynamic marketplace, companies are under competitive pressure to become more customer focused and more cost effective management plan is just the starting to continuously improvement in quality towards sustainability (Low and Leong 2001). Therefore, there is an urgent need for green management system that applicable to the Malaysian construction industry that is easy of use, adaptable, flexible and environmentally friendly.

In Malaysia, Construction Industry Development Board (CIDB) has initialised the Green Technology programme since 1999 as an environmental development programme initiative with the establishment of "Technical Committee" known as "TC9". The committee identified the main direction and several proposals in order to strengthen environmental practice in construction industry. The purpose of the establishment of the technical committee is to help CIDB to identify, prepare and develop the Construction Industry Standard (CIS), guidelines manual, technical reports, training modules and other materials associated with green technology in the construction industry. All of the taken initiatives and conducted programmes proved CIDB's strong commitment in improving and strengthening best green technology practices in the construction industry in Malaysia (CIDB Malaysia 2013).

Issues of sustainability have been duly highlighted in the Construction Industry Master Plan (2011-2015) as being of a new benchmark for the Malaysian construction industry. This is crucial in the view of much attention being paid to environmental issues. Green Building Index (GBI) was developed by both Pertubuhan Arkitek Malaysia (PAM) and the Association of Consulting Engineers Malaysia (ACEM) in 2009. Both of this organisation work hand in hand to lead the construction industry towards sustainability. From its beginning, GBI has received full support of Malaysia government and construction players. It is an initiative to promote sustainability and create more eco-friendly product in the construction and raise awareness among stakeholders. Previous studies (Lam et al. 2009) have proposed green specification guides and a common database for overcoming the difficulties in applying green building practice in the industry. A model for green specifying is considered necessary for striving ahead in raising the awareness of stakeholders towards sustainable construction.

Thomson and El-Haram (2014) stated that action plans is paramount in sustainability. It has a future for managing the delivery of sustainability through project management. Construction players not merely look at time, cost, quality and safety but there is a need to ensure a sustainability action plan is developed from inception to the post construction period. This is the basis of the project management so that an active consistent approach can be initiated.
This research has been carried out in an attempt to assess the contribution factors for the application of green management in the Malaysian construction industry. The government, semi government and private sector are eager to develop such a framework. With the contribution factors carried out in this research, it can further enhance and intensify the practice of sustainability in Malaysia. These factors can be the interest of developers and contractors in Malaysia. The internal and external factors will act as mediator and linkage for the betterment of the construction quality model framework and thus contribute to the body of knowledge.

\section{METHODOLOGY}

In this section, the methodology used a measurement instrument procedure, the data sample collected in this research being further analysed and presented. It is chosen for its simplicity and availability in any industry. The measurement instrument follows previous researchers' measures (Chileshe \& Watson 2003; Chileshe \& Watson 2004; Watson \& Chileshe 2003; Chileshe \& Sim 2007).

In this paper, there are several ways to achieve the aim of the research. Referring to Figure 1, Preliminary factors (internal and external) have been identified in previous research. This research aims to take a step ahead to draw a linkage to green management practices in Malaysia. This is done through confirmatory factor analysis (CFA). It is carried out for all the constructs. Content validity at the item level measures the target or content domain which it is supposed to measure and as the instrument has been developed based on the effective management of complex change (Abraham et al. 1997) and the 'Internal external factors', therefore ensuring validity since the instrument has been previously tested in several studies ranging from manufacturing to services. Then, the reliability issues are addressed through the following measures is used in this paper for the reliability tests namely; Cronbach Alpha and Kaiser-Meyer-Oklin (KMO) sampling. Because of the small sample, a measure of the sampling adequacy using the Kaiser-Meyer-Oklin (KMO) was carried out and the results obtained was a value of 0.768 . It is recommended that the value of KMO should be greater than 0.5 if the sample is adequate (Field 2000). The result of 0.791 indicates that the analysis was strongly supported for each factorial determination. The KMO statistic varies between 0 and 1 , and is defined as a method for comparing the magnitude of the correlation coefficients to the magnitudes of the partial correlation coefficients.

The importance of developing validate measures are articulated by several researchers (Nunnally 1978; Saraph et al. 1989; Madu 1998). Several dimensions of validity need to be run such as content validity, construct validity and criterion-related validity (Flynn et al. 1994). There are several development process in order to achieve that. The multidimensionality which is a mandatory condition for construct validity and reliability checking is addressed 


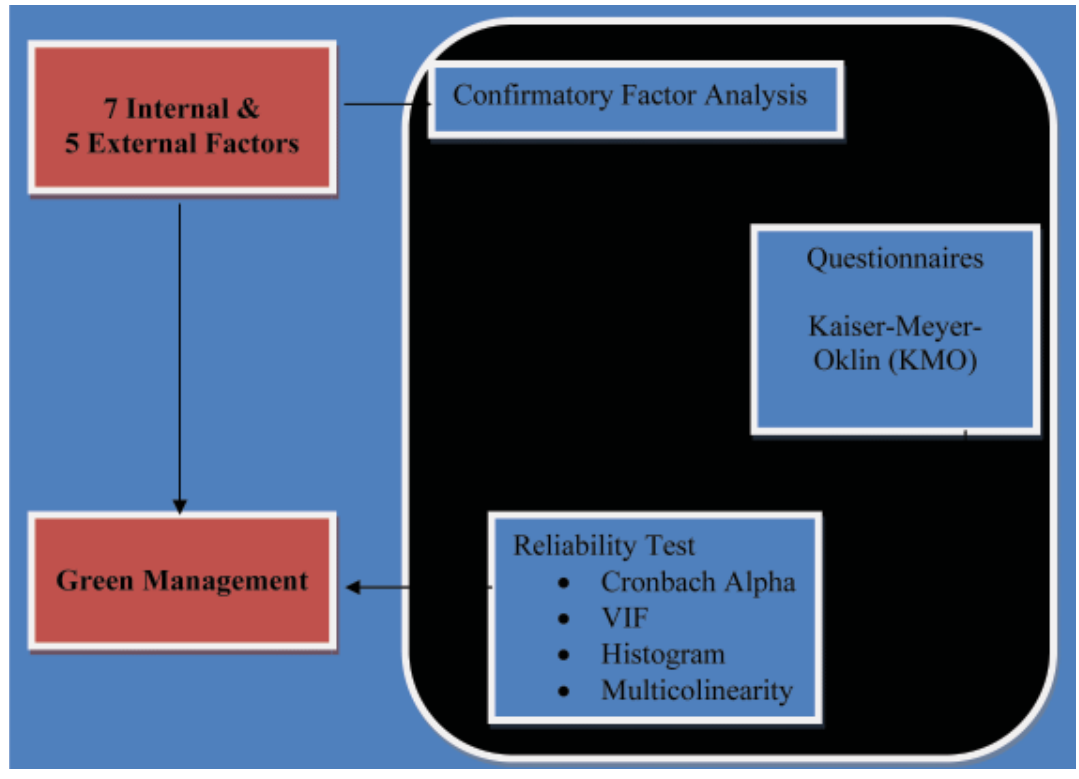

FIGURE 1. Research process

through a measurement model not shown in this paper was specified for the two constructs identified as management practices and internal/external factors.

The sample for the study consisted of 463 Malaysian constructional related organisations randomly selected from the CIDB Malaysia list of database. A total of 122 organisations responded giving a response rate of $25 \%$. Twenty of the responses were unusable due to incomplete data. The data collected from analyses are based on the remaining 102 organisations. An internal consistency analysis was carried out to the twelve internal and external factors. Both instruments had high Cronbach alpha values with the motivation for certification achieving 0.753 and 0.813 indicating a high reliability as values are $>0.7$. (Nunnally 1978). While the internal and external factors instrument had a high reliability $(0.7575$ and 0.7659$)$. This item displayed a strong positive relationship to the total indicates the question that is good on reliability and thus affecting the findings from the whole scale.

\section{DISCUSSION OF FINDINGS}

Figure 2 shows that the position of individual respondents were assessed and the majority of the respondents workers were 22 director2/assistant director2 (23\%), three head of finance/marketing (3\%), seven (7\%) quantity surveyors, fifteen $(15 \%)$ project and construction managers, six $(6 \%)$ architects, eighteen (18\%) engineers, one (1\%) lecturer, eight $(8 \%)$ consultants, eight $(8 \%)$ quality managers, five $(5 \%)$

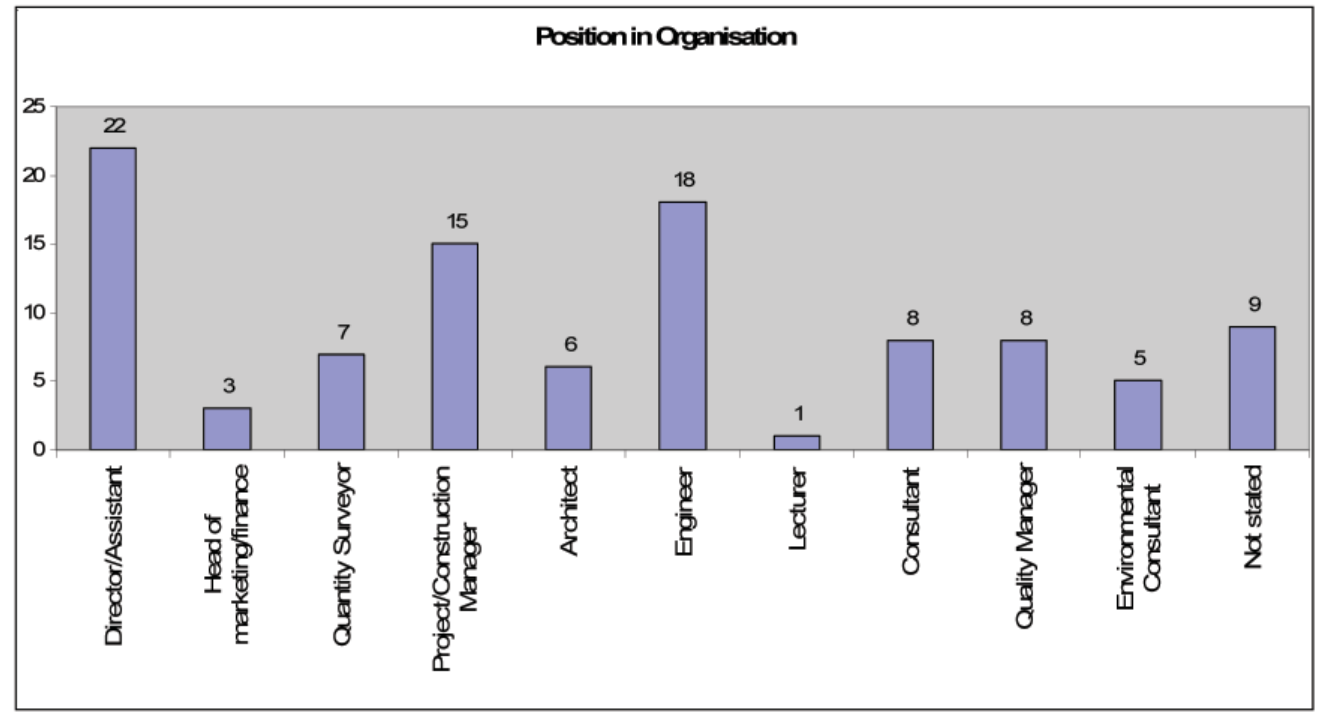

FIGURE 2. Background of respondents 


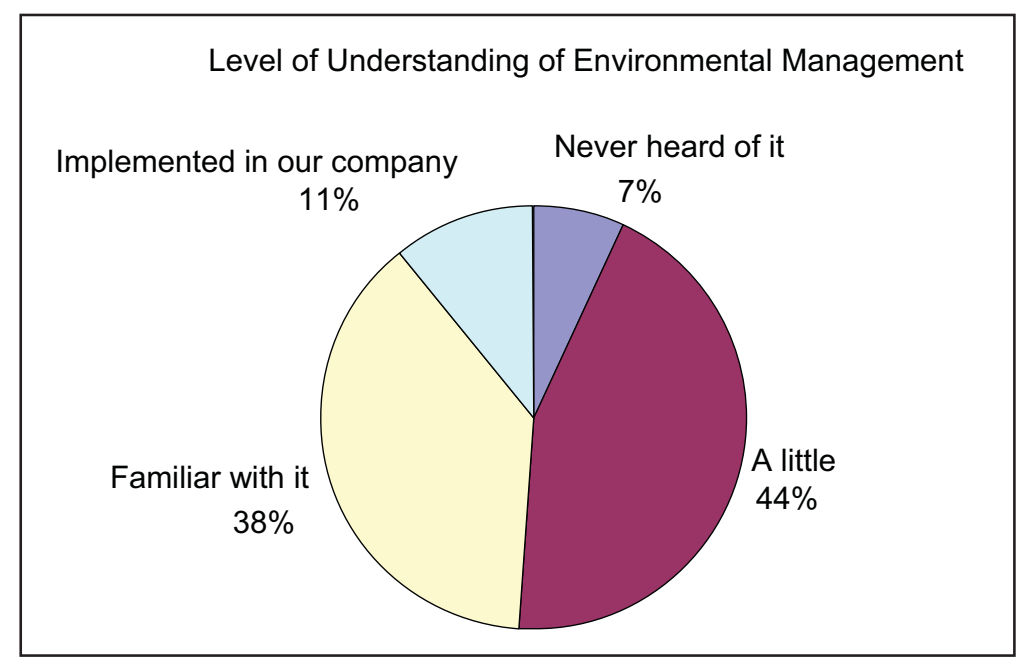

FIGURE 3. Level of understanding of environmental management

environmental consultants and another nine (9\%) not stated due to privacy issue.

Furthermore, each had been involved in the construction industry for a considerable period with a maximum of forty years and minimum of three years. This implies that they had enough knowledge and practical experience within the quality and green management system. Referring to Figure 3 , the level of understanding of environmental management is significant (93\%) and only $7 \%$ are not aware of it.

TABLE 1. Descriptive statistics \& results of internal consistency analysis for internal factors

\begin{tabular}{lccc}
\hline Internal Factors (Variable) & Rank & Mean & StDev \\
\hline Management commitment & 4 & 3.3762 & 1.0757 \\
Requirements of standards & 4 & 3.3762 & 1.0567 \\
Documentation & 5 & 3.3069 & 1.0271 \\
Training & 2 & 3.4455 & 0.9947 \\
Resistance to change & 3 & 3.3960 & 0.9382 \\
Usage of computer technology & 6 & 3.3030 & 1.0547 \\
Environmental/Green technology & 1 & 3.6733 & 0.9392 \\
\hline
\end{tabular}

Each and every of the internal factors is considered having significant effect on green implementation. These are shown by mean value ranging from 3.3030 to 3.6733 (all items above 3.00) as shown in Table 1. However, just three highest mean values on top of the list will be selected for analyst. The reason behind is to incorporate only the internal values that are considered more important into the research framework. Therefore, only three variables are chosen i.e. 'Environmental/Green Technology', 'Training' and 'resistance to change' which has value of 3.6733, 3.4455 and 3.3960 respectively. Basically, a small standard deviation for internal factors means that the values in a statistical data set are close to the mean of the data set, on average.
TABLE 2. Descriptive statistics \& results of internal consistency analysis for external factors

\begin{tabular}{lccc}
\hline Internal Factors (Variable) & Rank & Mean & StDev \\
\hline Demanding Global Customers & 4 & 3.4059 & 0.9293 \\
Shifting Customer Expectations & 3 & 3.4509 & 0.9506 \\
Opposing Economic Pressures & 5 & 3.3663 & 0.9697 \\
New Approaches to Management & 2 & 3.5149 & 0.9513 \\
Integration with Environmental & 1 & 3.6040 & 0.9600 \\
Management & & & \\
\hline
\end{tabular}

Each and every of the external factors is considered having significant effect on green implementation. These are shown by mean value ranging from 3.6040 to 3.3663 (all items above 3.00) as shown in Table 2. However, just three highest mean values on top of the list will be selected for analyst. The reason behind is to incorporate only the external values that are considered more important into the research framework. Therefore, only three variables are chosen i.e. 'Integration with Environmental Management', 'New Approaches to Management' and 'Shifting Customer Expectations' which has value of 3.6040, 3.5149 and 3.4509 respectively. A small standard deviation for external factors means that the values in a statistical data set are close to the mean of the data set, on average.

\section{RELIABILITY OF DATA}

The analysis will be meaningless unless the questionnaire is reliable. Reliability is the ability of the questionnaire to consistently measure the topic under study at different times and across different populations. (Hinton et al. 2004). The most popular method is the Cronbach's Alpha. 
TABLE 3. Reliability of data

\begin{tabular}{lccc}
\hline Categories & $\begin{array}{c}\text { Variables } \\
\text { No. }\end{array}$ & $\begin{array}{c}\text { Average } \\
\text { Cronbach } \\
\text { Alpha }\end{array}$ & $\begin{array}{c}\text { Result } \\
\text { Interpretation }\end{array}$ \\
\hline Internal Factors & 3 & 0.7575 & Acceptable \\
External Factors & 3 & 0.7659 & Acceptable \\
\hline
\end{tabular}

Cronbach's Alpha ranges from 0 to 1 . The higher the number, the more reliable is the sets of questionnaire. After the reliability test, it is found out that all section for the construction quality model is reliable. This is shown by the Cronbach's Alpha value of between 0.7575 and 0.7865 . Nunnally (1978) recommended that a value of 0.7 should be achieved. It is assumed that if alpha for any scale is greater than 0.7 then it is acceptable. As shown in Table 3 , the eleven variables are considered acceptable. These are the average of 11 items for the model framework. While 0.7575 is the value for the 3 internal factors, 0.7659 for external factors, 0.7592 for management practice variables and 0.7865 for cultural values variables. All variables displayed a reasonable positive relationship and reliable. In the words, the results of all variables are reliable. These again reconfirm the research findings.

In this research, there are four test used to determine the reliability of data presented in regression in Minitab. The four are - Normality test from histogram (Figure 4), multicolinearity and auto correlation (Table 4), and normal probability plot (Figure 5). The results of regressions are as follows:

Relationship - Internal External Factors to Green Policy
TABLE 4. Internal external factor to green policy multicolinearity and auto correlation analysis

\begin{tabular}{lc}
\hline Predictor Constant & $\begin{array}{c}\text { Variance Inflation } \\
\text { Factor (VIF) }\end{array}$ \\
\hline Resistance to Change (RC) & 1.704 \\
Green Technology (GT) & 1.458 \\
Shifting Customer Expectation (SC) & 1.399 \\
New Approach to Management (NA) & 1.476 \\
Integration with Environmental & 1.566 \\
Management (IE) & \\
Training (TR) & 1.521 \\
Durbin-Watson statistic & $=2.23684$ \\
\end{tabular}

The normality test of histogram is evenly distributed. The Normal probability plot test is along the positive relationship of linear line with just a few residuals. The constant VIF (1.399 to 1.704) of multicolinearity test is less than 7 which is good and the result of Durbin Watson statistic (2.2368) of autocorrelation test is between 1.5 and 2.5 , which is acceptable. Since relationship passed all the four tests of regression, we can conclude that relationship of internal and external factors towards green policy is statistically reliable (significant). Therefore, the hypothesis of the relationship is supported.

From the above regression analysis, we can conclude that the model suggest is the best fit in model as compare to the model suggest earlier. The model suggested earlier was accepted by looking at the Cronbach alpha and $p$-value. The latter model is better in terms of influencing the management practices factors. Therefore the mediator factors are accepted to further enhance the outcome of the implementation of the green policy nationwide.

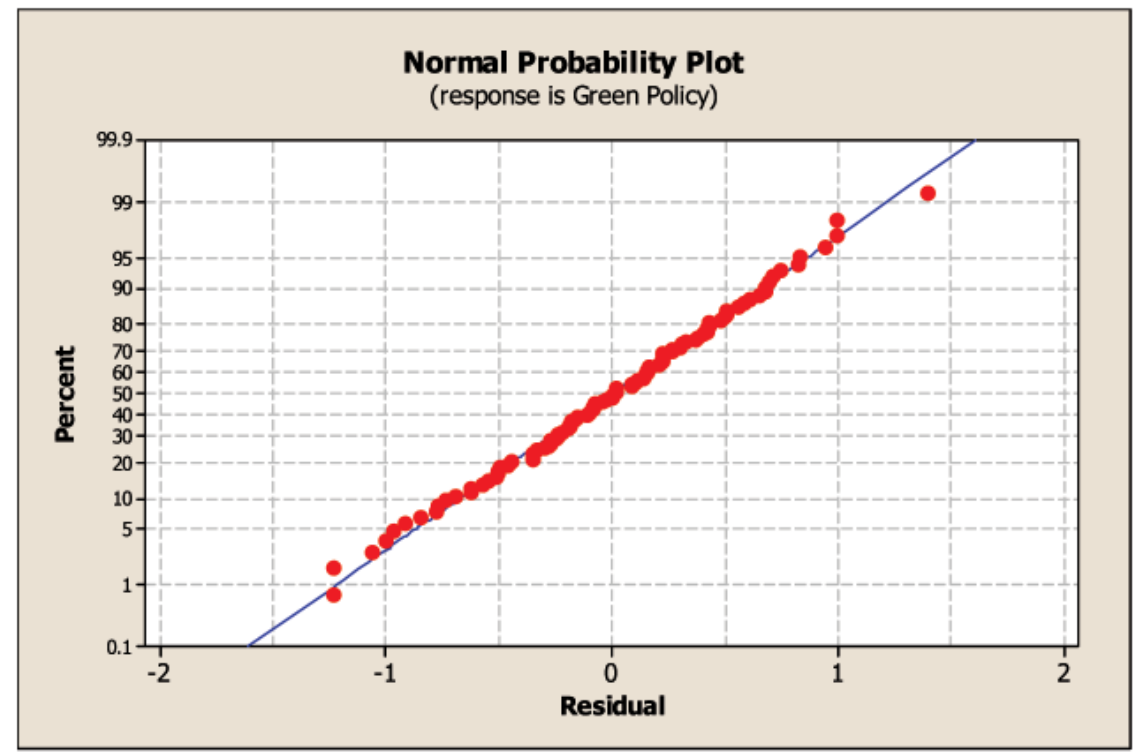

FIGURE 4. Internal external factor to green policy histogram 


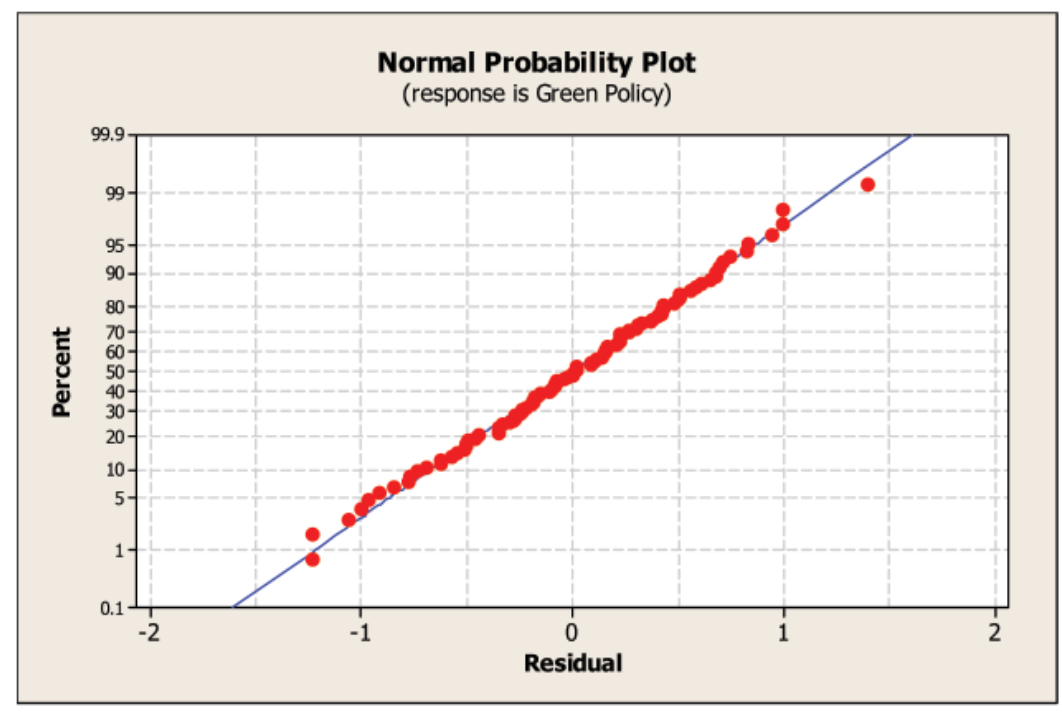

FIGURE 5. Internal external factor to green policy normal probability plot

\section{DISCUSSIONS}

Based on the quantitative result analysis by using Minitab Statistical software analysis, in this research, a theoretical model was hypothesized. The intention was to combine the entire identified six internal and external factors implementation constructs into one independent variable, which was used to test the relationships between green management implementation and internal and external factors.

Referring to Table 5, the statistical analysis findings revealed (Pearson $>0.400$ ) has three very positive effects that will impact green management which are; 1) management commitment, 2) demanding global customer and 3) training.

TABLE 5. Pearson correlation and P-value analysis

\begin{tabular}{|c|c|c|c|c|c|}
\hline No & Hypothesis & Relationship & $\begin{array}{c}\text { Value of } \\
\text { Pearson } \\
\text { Correlation }\end{array}$ & $\begin{array}{l}\mathrm{P} \text {-Value } \\
\text { (T-test) }\end{array}$ & $\begin{array}{c}\text { Analysis Relationship and Null } \\
\text { Hypothesis Ho }\end{array}$ \\
\hline 1 & $\mathrm{H} 1$ & $\begin{array}{l}\text { Green Management \& Management } \\
\text { Commitment }\end{array}$ & 0.497 & 0.003 & $\begin{array}{l}\text { Moderate Positive relationship and } \\
\text { reject null hypothesis }\end{array}$ \\
\hline 2 & $\mathrm{H} 2$ & $\begin{array}{l}\text { Green Management \& Interpreting the } \\
\text { Requirements of the Standards }\end{array}$ & 0.310 & 0.275 & $\begin{array}{l}\text { Moderate Positive relationship do not } \\
\text { reject null hypothesis }\end{array}$ \\
\hline 3 & H3 & Green Management \& Documentation & 0.028 & 0.778 & $\begin{array}{l}\text { Weak Positive relationship and do not } \\
\text { reject null hypothesis }\end{array}$ \\
\hline 4 & $\mathrm{H} 4$ & $\begin{array}{l}\text { Green Management \& Resistance } \\
\text { to Change }\end{array}$ & 0.255 & 0.010 & $\begin{array}{l}\text { Moderate Positive relationship and } \\
\text { reject null hypothesis }\end{array}$ \\
\hline 5 & H5 & $\begin{array}{l}\text { Green Management \& Usage of } \\
\text { Computer Technologies }\end{array}$ & 0.234 & 0.019 & $\begin{array}{l}\text { Moderate Positive relationship and } \\
\text { reject null hypothesis }\end{array}$ \\
\hline 6 & H6 & $\begin{array}{l}\text { Green Management \& Environmental/ } \\
\text { Green technology }\end{array}$ & 0.233 & 0.019 & $\begin{array}{l}\text { Moderate Positive relationship and } \\
\text { reject null hypothesis }\end{array}$ \\
\hline 7 & $\mathrm{H} 7$ & Green Management \& Training & 0.473 & 0.006 & $\begin{array}{l}\text { Moderate Positive relationship and } \\
\text { reject null hypothesis }\end{array}$ \\
\hline 8 & $\mathrm{H} 8$ & $\begin{array}{l}\text { Green Management \& Demanding } \\
\text { global customers }\end{array}$ & 0.466 & 0.097 & $\begin{array}{l}\text { Moderate Positive relationship and } \\
\text { reject null hypothesis }\end{array}$ \\
\hline 9 & H9 & $\begin{array}{l}\text { Green Management \& Shifting } \\
\text { customer expectations }\end{array}$ & 0.213 & 0.032 & $\begin{array}{l}\text { Moderate Positive relationship and } \\
\text { reject null hypothesis }\end{array}$ \\
\hline 10 & $\mathrm{H} 10$ & $\begin{array}{l}\text { Green Management \& Opposing } \\
\text { economic pressures }\end{array}$ & 0.294 & 0.000 & $\begin{array}{l}\text { Strong Positive relationship and reject } \\
\text { null hypothesis }\end{array}$ \\
\hline 11 & H11 & $\begin{array}{l}\text { Green Management \& New } \\
\text { approaches to management }\end{array}$ & 0.333 & 0.001 & $\begin{array}{l}\text { Strong Positive relationship and reject } \\
\text { null hypothesis }\end{array}$ \\
\hline 12 & H12 & $\begin{array}{l}\text { Green Management \& Integration } \\
\text { with Environmental Management }\end{array}$ & 0.377 & 0.076 & $\begin{array}{l}\text { Weak Positive relationship and do not } \\
\text { reject null hypothesis }\end{array}$ \\
\hline
\end{tabular}


In addition, the statistical analysis findings revealed Pearson correlation value of less than 0.400 but more than 0.300 shows moderate impact on green management. These factors are new approaches to management, integration with environmental management and interpreting the requirements of standard.

The analysis of Pearson correlation coefficients obtained were acceptable thought the coefficient were not exceptionally high and also most of them were statistically significant. The most important for the present purpose is to determine how the factors influence the management practice and thus affect the cultural values to bring a commended framework for new green management model in construction.

In this research, the data collected from 102 construction companies were used to assess the contribution factors for the application of green management in the Malaysian construction industry. Contrary to what was hypothesized in the models, a number of hypotheses were not confirmed by the data. This disconfirmation does not imply these constructs are useless or unimportant. Instead, there's a need to identify the problem areas of these constructs and implement them more effectively. The training and environmental education must be in action to ensure the successful implementation of green management.

Therefore, these constructs were identified making the interpretation of these variables (constructs) more valid. Finally, there is a model framework being produced for the evaluation and adoption of green management within the Malaysian construction industry. This framework is totally formulated on the basis of the results from the research.

\section{CONCLUSIONS}

Seven internal factors correlated with five different external factors for green policy deployment. In summary it can be stated that the overall level of awareness and readiness of green deployment within Malaysian Construction Organisations is medium-high. Thus, the objective of this paper which is 'Assessing the Contribution Factors for the Application of Green Building Index in the Malaysian Construction Industry' has been fulfilled, both in an objective and subjective way. The study provided a raft of contributions, both theoretical and practical. The literature reviews for primary objectives of CIDB Malaysian and GBI has been defined and identified. The six constructs identified as the internal and external factors that can motivate deployment of green policy are just one of the pillars for the building. Motivation without the way of practices is meaningless. The in depth review from the literature is therefore important to support and sustain the constructs mentioned above. In addition, the extensive literature review managed to identify some internal and external factors such as management commitment, demanding global customer, training, new approaches to management, integration with environmental management and interpreting the requirements of standard. Although the descriptive statistics used in this research paper are taken from within the Malaysian Construction Industry, the impact of Management Practices and Internal and External factors and its associated benefits of Environmental Management deployment are universal and probably of interest to the other countries.

\section{ACKNOWLEDGMENT}

The main author as $\mathrm{PhD}$ candidate has been supported by Mybrain15 scholarship programme under the Malaysian Ministry of Higher Education.

\section{REFERENCES}

Abraham, M., Crawford, J. \& Fisher, T. 1998. Key factors predicting effectiveness of cultural change and improved productivity in implementing total quality management. International Journal of Quality \& Reliability Management 16(2): 112-132.

Chileshe, N. \& Watson, P. A. 2003. A Survey of TQM Implementation within UK Construction SME's. In Proceedings of the Second International Conference on Construction in the 21st Century. Sustainability and Innovation in Management and Technology (CITC-II), Hong Kong, December 10-12, ISBN 988-97370- 1- 9: 226-231,

Chileshe, N. \& Sim, Y. L. 2007. Desirable Management Practices and Cultural Values for Construction Quality Assessment Systems (CONQUAS): Methodology for Assessment. In Proceedings of the 23rd Annual ARCOM Conference, 3-5 September 2007, Association of Researchers in Construction Management, Belfast, UK, edited by Boyd, D., 557-558.

Chileshe, N. \& Watson, P. 2004. The measurement of quality management levels within UK construction SME's: development and validation of TQ-SMART, In: Khosrowshahi, F. (Ed), 20th Annual ARCOM Conference, 1-3 September 2004, Heriot Watt University, Association of Researchers in Construction Management 1: 77-88.

CIDB Malaysia Green Technology (Program CIDB Alam Teknologi Hijau) Online. Retrieved on: 23th March 2013. http://www.CIDB.gov.my/v6/files/prog/CIDBBookletGreenTech.pdf.

Field, A. 2000. Discovering Statistics Using SPSS for Windows. SAGE Publications.

Flynn, B. B., Schroeder, R. G. \& Sakakibara, S. 1994. A framework for quality management research and associated measurement instrument. Journal of Operations Management 11: 339-366.

Hinton, P., Brownlow, C., McMurray, I. \& Cozens, B. 2004. SPSS Explained. London: Routledge.

Lam, P. T. I., Chan, E. H. W., Chau, C. K., Poon, C. S. \& Chun, K. P. 2009. An overview of the development of green specifications in the construction industry worldwide, International Sustainable and Urban Regeneration: Case Studies and Lessons Learned, ICONUS, Earthscan, London: 86-93. 
Low, S. P. \& Leong, H. Y. 2001. Asian management style versus Western management theories: A Singapore case study in construction project management. Journal of Managerial Psychology 16(2): 127-141.

Madu, C. N. 1998. An empirical assessment of quality: Research consideration. International Journal of Quality Science 3(4): 348-355.

Nunnally, J. 1978. Psychometric Theory. $2^{\text {nd }}$ edition. New York: New York, McGraw-Hill.

Saraph, J. V., Benson, P. G. \& Schroeder, R. G. 1989. An Instrument for measuring the critical factors of quality management. Decision Sciences 20: 810-829.

Sim. Y. L. 2015. Towards Implementation and Achievement of Sustainability in the Malaysian Construction Industry, $\mathrm{PhD}$ Thesis, University Malaysia Sarawak, Malaysia

\author{
Yeong Liang Sim* \\ Frederick Putuhena \\ Puong Ling Law \\ Azhaili Baharun \\ Faculty of Civil Engineering, \\ University Malaysia Sarawak, Malaysia
}

*Corresponding author; email: captivesim@yahoo.com

Received date: $3^{\text {rd }}$ October 2014

Accepted date: $1^{\text {st }}$ April 2015
Thomson, C. \& El-Haram, M. 2014. Potential and implications of sustainability action plans: Lessons from the Greater Middlehaven regeneration project. Built Environment Project and Asset Management 4(1): 108-122.

Watson, P. A. \& Chileshe, N. 2003. Deploying and scoring the European Foundation for Quality Management Excellence Model (Part One). $2^{\text {nd }}$ International Structural Engineering and Construction Conference, (ISEC-02), Rome, Italy, Sept 23-26, ISBN 905809599 1, 1: 15951598.

Wikipedia 2014. The Free Encyclopedia [Online]. Retrived on: 25th June 2014 http://en.wikipedia.org/wiki/Lego. 